\title{
波浪の数值シミュレーションを 考慮した数值ナビゲーションについて
}

塩谷 茂明*

\section{On Numerical Navigation for a Ship Using Numerical Simulation of Waves}

\author{
Shigeaki SHIOTANI Eiichi KOBAYASHI \\ Teruo OHSAWA and Hidenari MAKINO
}

\begin{abstract}
This paper deals with the numerical simulation of navigation based on the ocean waves for the purpose of the optimum routing of a small vessel which sails in the relatively narrow sea area such as the bay. In former part of this paper, the computational simulation of the ocean waves of Osaka Bay was explained. The ocean wave was calculated by numerical model of SWAN. In latter parts of it, the numerical simulation of navigation in the bay was carried out.
\end{abstract}

The effects of the ocean waves to navigation by a small vessel were examined numerically. As results, it was recognized that effects of ocean waves to navigation are very large and that the simulation of ocean waves for the weather routing of a small vessel is very effective.

Keywords : Numerical navigation, SWAN model, MMG, RIOS, Weather routing キーワード: 数值ナビダーション, SWAN モデル、MMG，RIOS, ウェザールーティング

\section{1.はじめに}

沿岸が航行海域の小型船舶も、大洋航海上同様に 気象・海象の影響により、計画航路からの偏位や船 速低下等に遭遇する。状況次第では、衝突や座礁等 の海難発生の要因になる。逆に、気象・海象を事前 に予測し利用すると、高波高や強風を伴う荒天域の 適切な避航操船が可能となり、海難防止に役立つ。 また、潮流や海流を利用する適切な航路選定により、 安全性と経済的効果を追求した最適航法の実現が可 能である。本研究の最終目的は、湾内や沿岸域等の 比較的狭い海域内の小型船舶に対し、出航前に航海
中に遭遇するであろう気象・海象の数値予測と航海 中に収集された各種航海情報から、安全性と経済的 効果の高い最適航法システムを構築することである。

これまで著者らは航行船舶の船位を正確に予測で きる手法として、船舶操縦性能理論を導入し、航行 海域内の潮流及び海上風の影響について、実船実験 及び数值航海シミュレーションにより論じた(1) (8)。 実海域上で潮流または風の相対方位と船体横流れ量 及び航程の変化について調查した。実験結果の検証 は、数值シミュレーションで得られた潮流、海上風 の中を、模擬船舶が一定針路で航行する航海シミュ

\footnotetext{
* 正会員 神戸大学自然科学齐先端融合研究環 （ shiotani@maritime.kobe-u.co.jp

** 正会 員 神戸大学大学院海事科学研究科
} 
レーションによる横流れ量と航程の予測との比較か ら行った。その結果、航海シミュレーションによる 航行船舶の船位推定が概初可能であることを確認し た。

本研究では、船舶への波浪影響による航行船舶の 横流れ量及び航程の予測が目的であり、波浪の数值 シミュレーションと波浪中の航海シミュレーション が可能な手法の開発を行った。数值シミュレーショ ンの結果、本手法が有効であることがわかったので、 ここに報告する。

\section{2. 波浪予報の数値シミュレーション 2.1 SWAN $の$ 概要}

海洋・沿岸海域の開発計画策定にあたり、計画海 域内の波浪特性の把握の必要性から、多数の波浪推 算モデルが開発・利用されてきた。代表的なモデル として、WAM、SWAN 等がある(9)(10)。WAM は深海 域を対象とした波浪推算モデルであり、SWAN は WAM の改良版であり、浅海域を含む海域での波浪 推算が可能であるそデルである。WAM で考慮され ていた風から波へのエネルギー輸送、4 波共鳴非線 形相互作用による成分波間でのエネルギー輸送、白 波砕波によるエネルギー散晩、底面摩擦によるエネ ルギー散逸に、SWAN では浅水砕波によるエネルギ 一散逸、極浅海域で顕著となる 3 波共鳴非線形相互 作用による成分波間でのエネルギー輸送など、浅水 域での波浪伝搬を加えている。

SWAN はオランダのデルフト工科大学で開発され たモデルで、風波の方向スペクトル形状の相似性の 過程をしないで、波浪方向スペクトル成分波間の非 線形相互作用を評価した第 3 世代波浪推算モデルで ある。これによって、方向スペクトルの時空間変化 まで再現できるので、浅海域で発生する複雑な波浪 変形の推定も可能である。

本研究では、このような利点を生かした SWAN モ デルを航海シミュレーションにおける波浪予報とし て採用した。

\section{2 基礎方程式}

各計算格子上での波浪方向スペクトル $\mathrm{E}(\sigma, \theta)$ を変 数としているが、モデル内では 2 次元の波浪作用密 度スペクトル $\mathrm{N}(\sigma, \theta)$ を用いている。ここに、 $\sigma 、 \theta$ は それぞれ流れがある場合において流れと共に移動す る座標系から見た各周波数、方向角である。両者に は、次式の関係がある。

$$
N(\sigma, \theta)=\frac{E(\sigma, \theta)}{\sigma}
$$

これは、流れが存在する場合では、波浪方向スペク トルは保存されないが、波浪の作用スペクトルは保 存量であるから、後者を使用する。

2 次元の波浪作用密度スペクトル $\mathrm{N}(\sigma, \theta)$ に関する平 衡方程式、直交 2 次元 $(x, y)$ 空閒上では、次式で表さ れる。

$\frac{\partial}{\partial t} N+\frac{\partial}{\partial x}\left(c_{x} N\right)+\frac{\partial}{\partial y}\left(c_{y} N\right)+\frac{\partial}{\partial \sigma}\left(c_{\sigma} N\right)+\frac{\partial}{\partial \theta}\left(c_{\theta} N\right)$

$=\frac{S(\sigma, \theta)}{\sigma}$

ここに、 $c_{\mathrm{x}} 、 \mathrm{c}_{\mathrm{y}} 、 \mathrm{c}_{\sigma} 、 \mathrm{c} 、 \theta$ はそれぞれ実空間 $\mathrm{x} 、 \mathrm{y}$ 及 びスペクトル空間 $\sigma 、 \theta$ 上での伝搬速度である。各成 分波の位相速度 $\mathrm{c}$ と群速度 $\mathrm{c}_{\mathrm{g}}$ 、定常流流速ベクトル $\mathrm{U}=(\mathrm{U}, \mathrm{V})$ 、波数ベクトル $\mathrm{\kappa}=\left(\mathrm{k}_{\mathrm{x}}, \mathrm{k}_{\mathrm{y}}\right)$ を用いて、次式 で表される。

$c_{x}=c_{g} \cos \theta+U$,

$c_{y}=c_{g} \sin \theta+V$,

$c_{\sigma}=\frac{\partial}{\partial t}(\sqrt{g k \tanh (k h)}-\kappa \cdot U)$

$c_{\theta}=\frac{c_{g}}{c}\left(\sin \theta \frac{\partial c}{\partial x}-\cos \theta \frac{\partial c}{\partial y}\right)$

$-\left(\sin \theta \frac{\partial}{\partial x}-\cos \theta \frac{\partial}{\partial y}\right)\left(\frac{\kappa}{k}\right)$

(2)式の左辺第 1 項は作用密度 $\mathrm{N}$ の時間変化、第 $2 、$ 3 項は $\mathrm{x}$ 方向扝よび $\mathrm{y}$ 方向の伝搬による空間変化、 第 4 項は水深と流れの時間変化による相対的な各周 波数の変化、第 5 項は水深や流速の空間分布に上る 波の屈折を意味寸る。右辺の $\mathrm{S}(\sigma, \theta)$ はこのシステム のエネルギーの入出を表すエネルギーのソース関数 を示し、次式で表される。

$S(\sigma, \theta)=S_{i n}+S_{d s}+S_{b r}+S_{b f}+S_{n l}+S_{t r i}$

ここに、 $\mathrm{S}_{\mathrm{in}} 、 \mathrm{~S}_{\mathrm{ds}} 、 \mathrm{~S}_{\mathrm{br}} 、 \mathrm{~S}_{\mathrm{bf}} 、 \mathrm{~S}_{\mathrm{n} 1} 、 \mathrm{~S}_{\mathrm{tri}}$ はそれぞれ、風 から波へのエネルギー輸送、白波砕波によるエネル ギ一散冕、浅水砕波によるエネルギ一散逸、海底摩 擦によるエネルギー消散、4 波波浪成分間での非線 形相互作用によるエネルギー輸送、3 波波浪成分間 での非線形相互作用によるエネルギ一輸送である。

\section{3 波浪の数值シミュレーション}

大阪湾を対象に SWAN を用いた波浪予報の数值 シミュレーションを行った。計算海域内の水深情報 として一定計算格子閒隔が $\Delta \mathrm{x}=\Delta \mathrm{y}=50 \mathrm{~m}$ 、格子数がそ 
れぞれ $1270 \times 1270$ の水深データを用いた。SWANに よる波浪計算では、このような詳細な解像度は必要 でなく、格子間隔が $\Delta x=\Delta y=1007.9 m$ 、格子数 $64 \times 64$ で行った。

Fig.1は発達した低気圧が日本海を通過した 2005 年 5 月 18 日 16 時及び 19 日9時の気象庁の天気図を 示す。発達した低気圧から伸びる温暖前線と寒泠前 線に挟まれた暖域内にある大阪湾に、強い南風が吹 き、低気圧が日本海を通過後、北西の風に転じた。

Fig.2 は海上風の数值予報の MM5 モデルにより、 Fig.1の天気図における 36 時間の数值シミニレーシ ヨンを行った、大阪湾の海上風の分布である。(a)図 では、強い南風が、(b)図では、北西風が吹いている。 南風の平均風速は $11 \mathrm{~m} / \mathrm{s}$ 、風向は $189^{\circ}$ 、北西風では

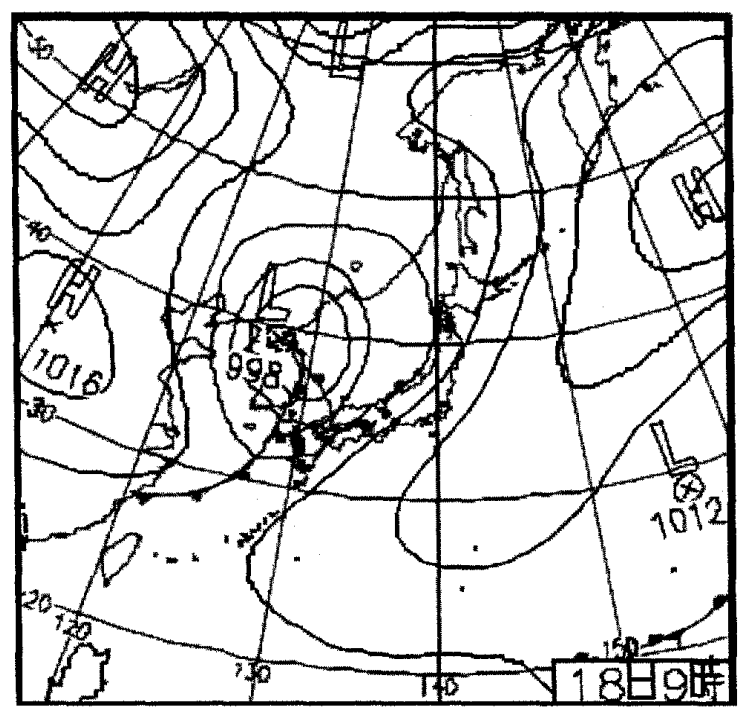

(a) At 16:00, May 18, 2005

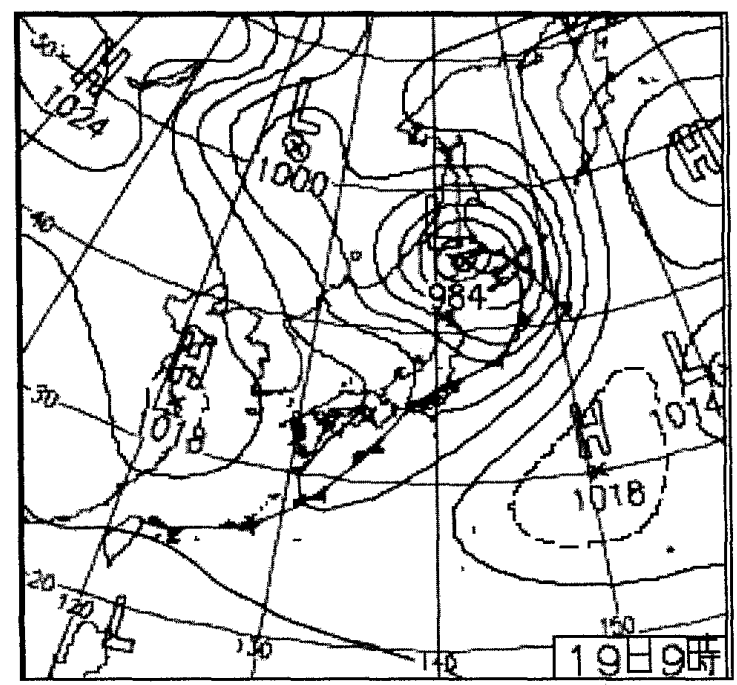

(b) At 09:00, May, 18, 2005

Fig.1 Weather chart on May 18-19, 2005 4m/s、3160である。

Fig.3 は著者らによるこれまでの風の数値シミュ レーションを行った研究における、MM5 モデルに よる数值シミュレーションから得られた大阪湾の海 上風に基づいた波浪の数值シミュレーション結果を 示す。MM5 に関する詳細は文献(8)に示す。(a)図は Fig.2(a)、(b)図は Fig.2(b)で示す風場の平均の風向、 風速の風が一定に吹いた時の、大阪湾で十分発達し た波である。上図は有義波高、下図は有義波周期を 示す。(a)図で大阪湾の海上の南風により、湾奥に向 かって次第に波浪が発達し、有義波高が最大約 $1.3 \mathrm{~m}$ 、 有義波周期が $3.5 \mathrm{~s}$ に成長している。(b)図では、北西

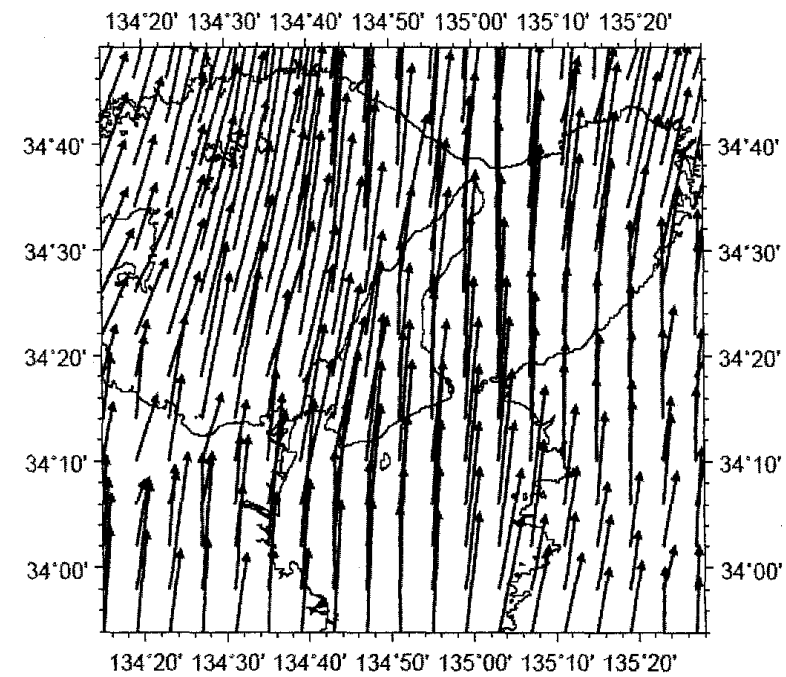

(a) At 16:00, May 18, 2005

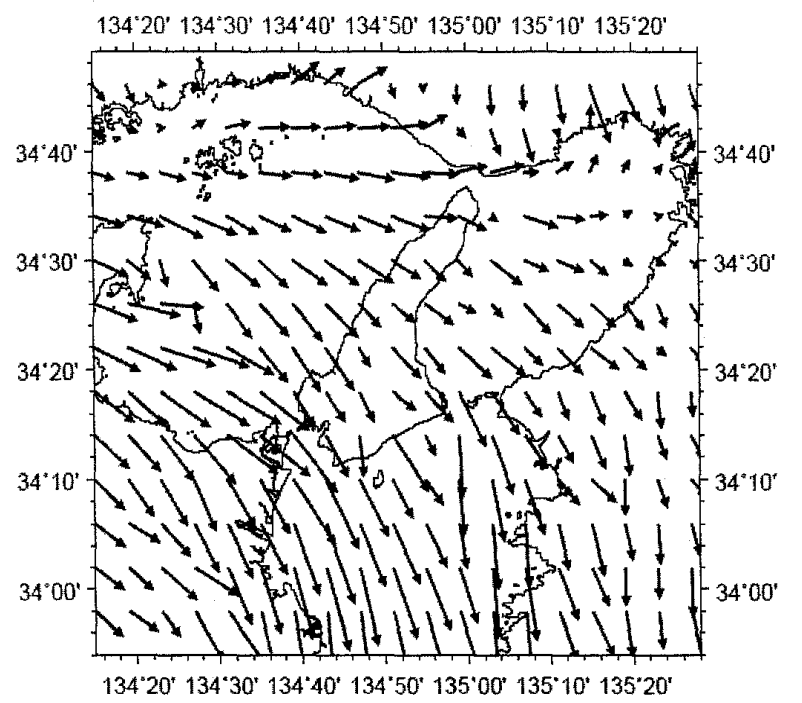

(b) At 09:00, May 19,2005

Fig.2 Simulated ocean surface wind in Osaka Bay 


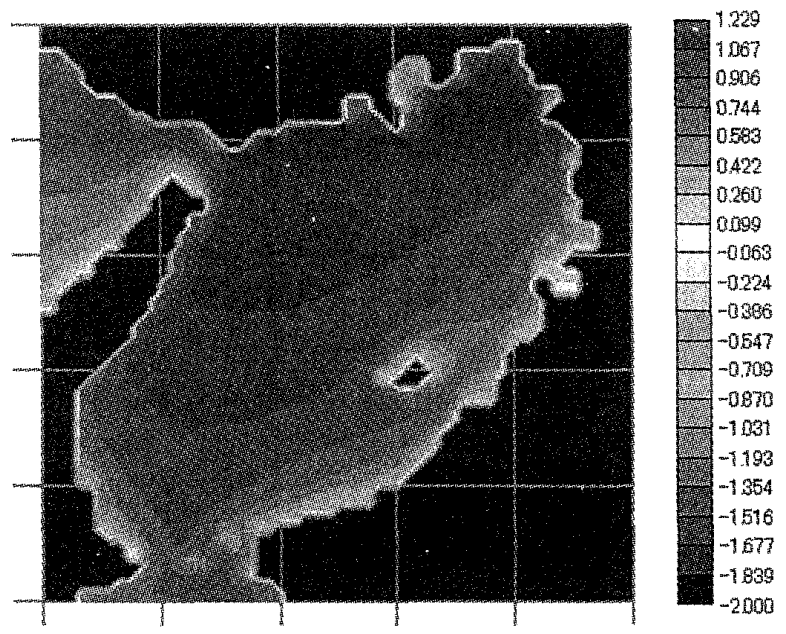

Significant wave height $(\mathrm{m})$

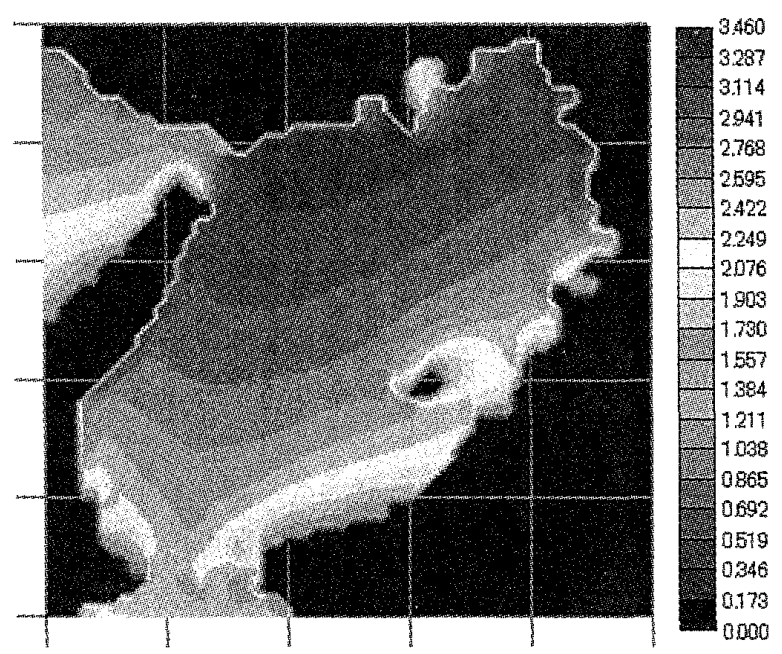

Significant wave period (s)

(a) At 16:00, May 18, 2005

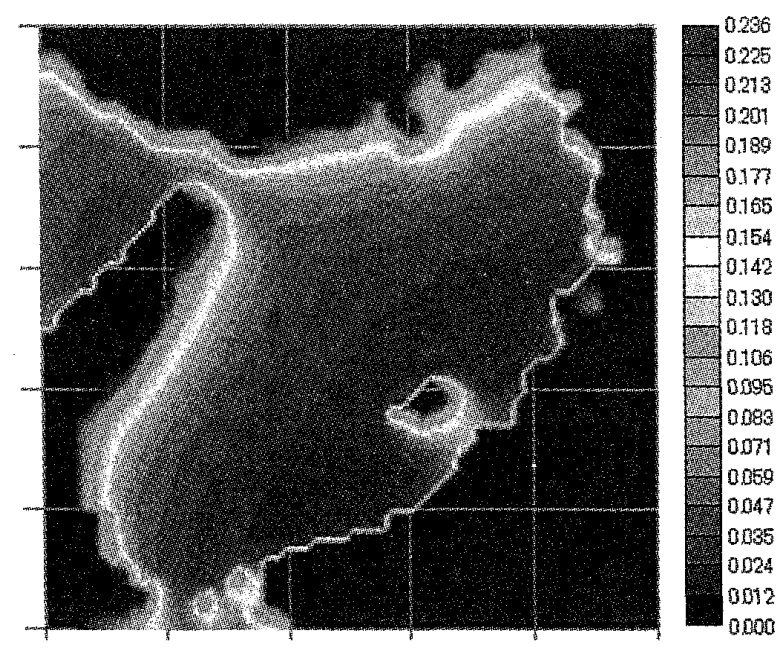

Significant wave height $(\mathrm{m})$

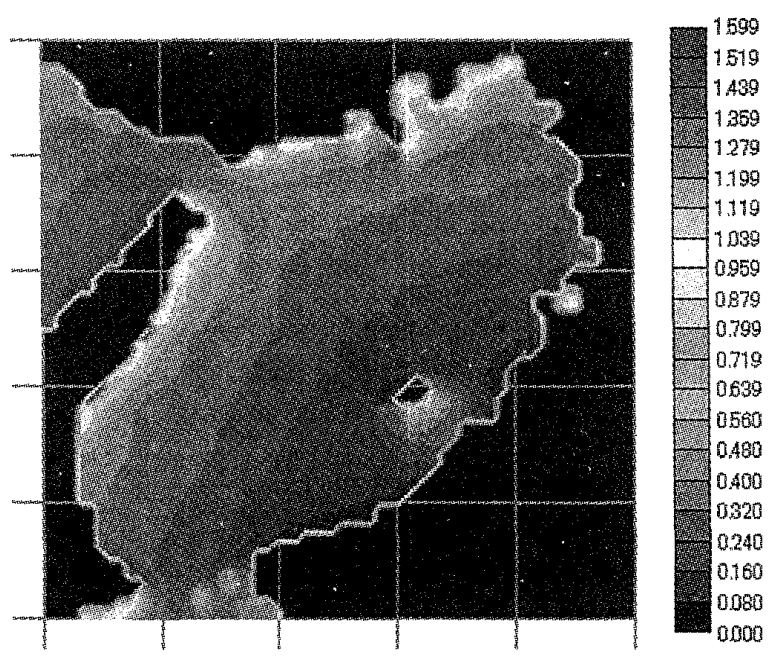

Significant wave period (s)

(b) At 09:00, May 19, 2005

Fig. 3 Simulated ocean waves in Osaka Bay

の風により、吹送距離が長い大阪湾の南東海域に高 波高域が見られる。

大阪湾内で波浪観測を実施する場所は少なく、シ ミュレーションと現地観測結果との厳密な比較は可 能でないが、それぞれ同じ傾向にある気象条件での 波浪を比較すると、SWANによる数值シミュレーシ ヨン結果は概ね良好であると思われる。また、SWAN モデルは、浅海域の計算が可能であり、沿岸部の浅 瀬域での波の減衰および特に、大阪湾南東部の海上 の関西空港周辺で、空港による風の遮蔽部分の波の 減衰も十分に計算されている。

以上の SWAN による波浪の数值シミュレーショ ン結果から、本手法による波浪の数值計算が有効で あることがわかった。

\section{3. 船舶操縦シミュレーション}

航行船舶は絶えず気象・海象の影響下にあり、設 定航路からの横流れや速力の減衰糹生じる。気象・ 海象の影響を考慮した正確な船位予測はウエザール 一ティングシステムの構築に極めて重要であり、横 流れ量が最小になる航路上に沿った正確な航海も可 能である。本研究では、船位予測に一般に利用され ている通常の操縦運動数学モデル $(\mathrm{MMG})$ を適用し た。Fig.4 は操縦運動モデルに用いた座標系を示す。 空間固定座標系 $0-\mathrm{x}_{0} 、 \mathrm{y}_{0}$ で定義された物理量を船の 重心 $\mathrm{G} の$ 加速度 $\ddot{x}_{0}$ 、、 $\ddot{y}_{0}$ および旋回運動の角加速 度 $\ddot{\psi} 、 \mathrm{x}_{0} 、 \mathrm{y}_{0}$ 方向の力 $\mathrm{X}_{0} 、 \mathrm{Y}_{0}$ および重心周りの回 頭モーメント $\mathrm{N}$ とする。船の操縦性能を論ずる場合、 船体上共に移動する船体固定座標系 G-x、y での記 
述が好都合であり、それぞれ $\mathrm{x} 、 \mathrm{y} 、 \psi 、 \mathrm{X} 、 \mathrm{Y} 、 \mathrm{~N} の$ 記号で表す。空間固定座標系を船体固定座標系に変 換後の船体運動方程式は次式で表される。

$$
\left.\begin{array}{c}
\left(m+m_{x}\right) \dot{u}-\left(m+m_{y}\right) v r=X \\
\left(m+m_{y}\right) \dot{v}+\left(m+m_{x}\right) u r=Y \\
\left(I_{z z}+J_{z z}\right) \dot{r}=N
\end{array}\right\}
$$

ここに、 $\mathrm{m}$ は船体の質量、 $\mathrm{I}_{\mathrm{zz}}$ は重心周りの慣性モー メント、 $m_{x} 、 m_{y}$ は $x 、 y$ 方向の付加質量、 $\mathrm{J}_{z z}$ は $\mathrm{z}$ 軸 回りの付加慣性モーメント、u、vは $\mathrm{x} 、 \mathrm{y}$ 方向の速 度成分、 $\dot{\psi}=\mathrm{r}$ である。

(5)式の右辺の船に㗢く力およびモーメントを船 体に㗢く力、プロペラ、舵、スラスタが発生する力、 風波、その他の外力による力に分けると次式で表さ れる。

$$
\left.\begin{array}{c}
X=X_{H}+X_{P}+X_{R}+X_{T}+X_{A}+X_{W}+X_{E} \\
Y=Y_{H}+Y_{P}+Y_{R}+Y_{T}+Y_{A}+Y_{W}+Y_{E} \\
N=N_{H}+N_{P}+N_{R}+N_{T}+N_{A}+N_{W}+N_{E}
\end{array}\right\}
$$

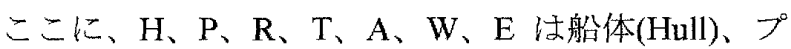
ロペラ(Propeller)、舵(Rudder)、スラスタ(Thruster)、 風(Air)、波(Wave)、外力(External force)寺している。 潮流の影響は潮流と共に移動する座標系として考 え、船体に㗢く流体力は次式を用いた。

$$
\begin{aligned}
X_{H}= & \frac{\rho}{2} L d U^{2}\left(X_{v v}^{\prime} v^{\prime 2}+X_{r r}^{\prime} v^{\prime 2}\right. \\
& \left.+X_{v v v v}^{\prime} v^{\prime 4}+X_{r r r}^{\prime} v^{\prime 4}\right)-R \\
Y_{H}= & \frac{\rho}{2} L d U^{2}\left(Y_{v}^{\prime} v^{\prime}+Y_{r}^{\prime} r^{\prime}+Y_{v v v}^{\prime} v^{\prime 3}\right. \\
& \left.+Y_{v v r}^{\prime} v^{\prime 2} r^{\prime}+Y_{v r r}^{\prime} v^{\prime} r^{\prime 2}+Y_{r r r}^{\prime} r^{\prime 3}\right) \\
N_{H}= & \frac{\rho}{2} L^{2} d U^{2}\left(N_{v}^{\prime} v^{\prime}+N_{r}^{\prime} r^{\prime}+N_{v v v}^{\prime} v^{\prime 3}\right. \\
& \left.+N_{v v r}^{\prime} v^{\prime 2} r^{\prime}+N_{v r r}^{\prime} v^{\prime} r^{\prime 2}+N_{r r r}^{\prime} r^{\prime 3}\right)
\end{aligned}
$$

ここに、 $\rho$ は海水密度、L は船長、 $d$ は喫水、Uは船 速、 $v^{\prime}=v / U 、 r^{\prime}=r L / U 、 R$ 注船体抵抗、Y'v, . . 等注 各種流体微係数である。

また、風圧力は次式で表される。

$$
\left.\begin{array}{c}
X_{A}=\frac{\rho_{A}}{2} V_{A}^{2} A_{T} C_{X A}\left(\theta_{A}\right) \\
Y_{A}=\frac{\rho_{A}}{2} V_{A}^{2} A_{L} C_{Y A}\left(\theta_{A}\right) \\
N_{A}=\frac{\rho_{A}}{2} V_{A}^{2} L A_{L} C_{N A}\left(\theta_{A}\right)
\end{array}\right\}
$$

ここに、 $\rho_{\mathrm{A}}$ は空気の密度、 $\theta_{\mathrm{A}}$ は相対風向、 $\mathrm{V}_{\mathrm{A}}$ は相 対風速、 $A_{T} 、 A_{L}$ 任船体水線上正面投影面積、船体水 線上側面投影面積、 $\mathrm{C}_{\mathrm{XA}} 、 \mathrm{C}_{\mathrm{YA}} 、 \mathrm{C}_{\mathrm{NA}}$ は風圧力係数で ある。

波浪の外力は次式で表される。

$$
\begin{aligned}
& X_{w}=\frac{1}{2} \rho g L h_{A}^{2} C_{X_{w}}\left(T_{V}, \theta_{w^{\prime}}, V_{s}\right) \\
& Y_{w^{\prime}}=\frac{1}{2} \rho g L h_{A}^{2} C_{Y_{w}}\left(T_{V}, \theta_{w}\right) \\
& Z_{w^{\prime}}=\frac{1}{2} \rho g L h_{A}^{2} C_{N_{w}}\left(T_{V}, \theta_{w}\right)
\end{aligned}
$$

$\mathrm{g}$ は重力加速度、 $\mathrm{h}$ は有義波振幅、 $\mathrm{C}_{\mathrm{Xw}} 、 \mathrm{C}_{\mathrm{Yw}} 、 \mathrm{C}_{\mathrm{Nw}}$ は波漂流力係数、 $\mathrm{T}$ は平均波周期、 $\theta$ は出会い方向、 Vは船速である。

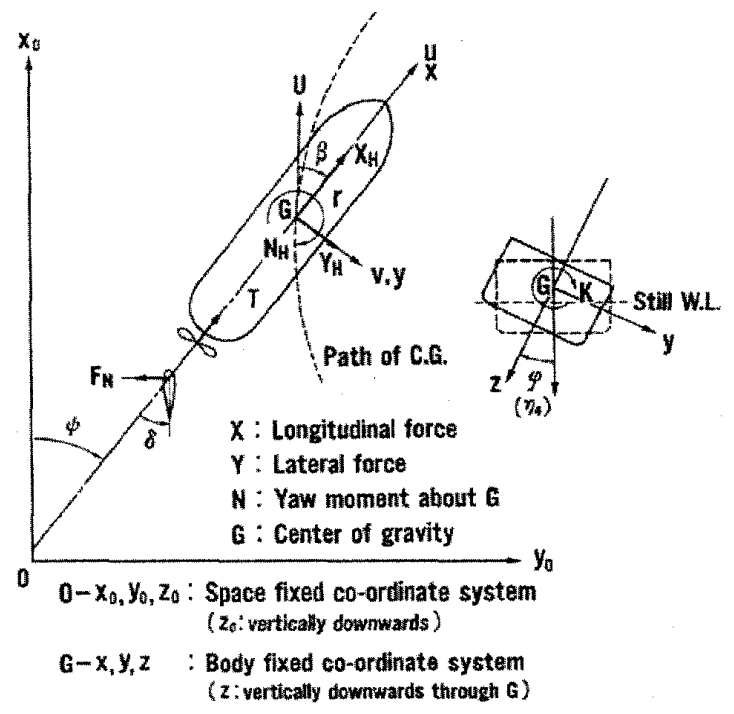

Fig.4 Coordinate system of ship maneuvering simulation

\section{4. 波浪中の定常力の計算}

波浪中の船体に加わる波浪定常力(抵抗増加、定常 横力、定常回頭モーメント)の計算はRIOSにより行 った。(13)

RIOSとは実海域船舶性能研究イニシアティブ(The Research Initiative on Oceangoing Ships)の略称であり、 大阪大学大学院工学研究科地球総合工学專攻船舶海 洋工学コースに設置された実海域での船舶性能の向 上と、船舶性能の評価手法に関する研究開発拠点で 
Table 1 Table IPrincipal properties of Fukaemaru

\begin{tabular}{lll}
\hline \multicolumn{2}{c}{ item } \\
\hline L. O. A. (m) & 49.95 \\
L.P.P. (m) & 45 \\
B. Md. (m) & 10 \\
Draft (m) & 3.2 \\
Gross T. (ton) & 449 \\
Max. Speed (kt) & 14.28 \\
Steering Eng. (kW) & 3.7 \\
Bow Thruster (kW) & 79 \\
Stern Thruster (kW) & 70 \\
Main Eng. Output (kW) & 1100 \\
Revolution (rpm) & 720 \\
Reduct. Ratio & $1 / 2.208$ \\
Propeller (C.P.P. Blades) & 4 \\
P. Dia. (m) & 2.1 \\
P. Pitch at 21.21 & (m) & 1.792 \\
\hline
\end{tabular}

ある。船舶が実海域を航行するとさの船舶性能の向 上と、船舶性能の評価手法を確立することにより、 世界の船舶の性能評価法を一新することを目的とし ている。

対象船舶の船体主要目、船図データ、船体断面形 状デ一夕を入力し、船速、波向、NL(波長/船長)、波 スペクトルを計算条件で指定して周波数応答関数の
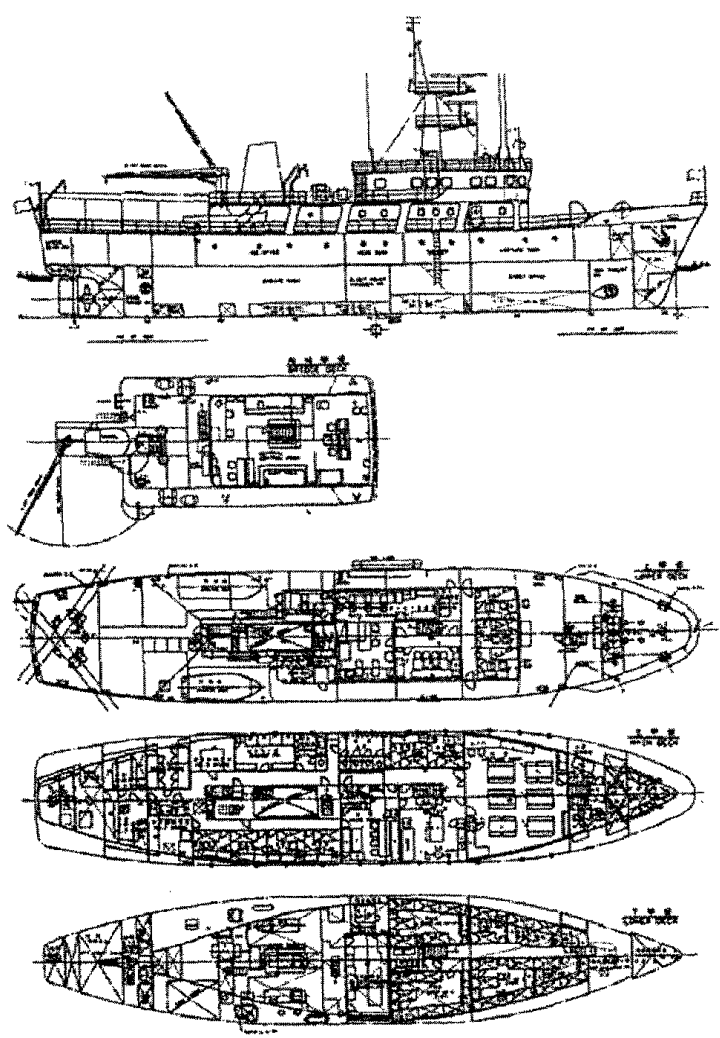

Fig. 5 General arrangement plan of an actual ship used in the experiments
計算を行い、波浪定常力(抵抗増加、定常横力、定常 回頭モーメント)を得る。そして周波数応答関数から 実海域における、波浪スペクトル、海象条件(有義波 高、平均波周期、相対波向)を入力して短期予測計算 を行い、波浪定常力の平均值を求好。

本研究では、供試船として、神戸大学大学院海事 科学研究科附属練習船「深江丸」を用いた。Table1 に深江丸の主要項目、Fig.5に供試船の一般配置図を 示す。深江丸は主に瀬戸内海及び周辺沿岸海域を航 行海域とし、1 日〜1週間程度の学生実習及び研究航 海に利用されている。

\section{5. 航海シミュレーション}

大阪湾に扔いて、供試船「深江丸」が波浪中を模 擬航海する航海シミュレーションにより、波浪影響 の調查を行った。Fig.6 は発達した低気圧が日本海を 通過して(Fig.1(a))、大阪湾に強い南風唯吹き (Fig.2(a))、波浪の数值シミュレーションで得られた 高波高域の波浪場(Fig.3(a))を航行する 4 種類の仮想 航路を示打。深江丸の針路は 045、225、090及び $270^{\circ}$ 、船速は $12.3 \mathrm{kn}$ で、それぞれ 1 時間航海した。 平均風速は $11 \mathrm{~m} / \mathrm{s}$ 、風向は $189^{\circ}$ 、平均有義波高は $1.0 \mathrm{~m}$ 、 周期は約 3s、さらにより現実的な海域での航海シミ エレーションの再現のため、大陙湾に执计る上げ潮 (北流) で $0.5 \mathrm{~m} / \mathrm{s}$ (約 1 ノット) の一定強さの潮流 を課した。

Fig.7 は Fig.6で設定された気象・海象下で、MMG

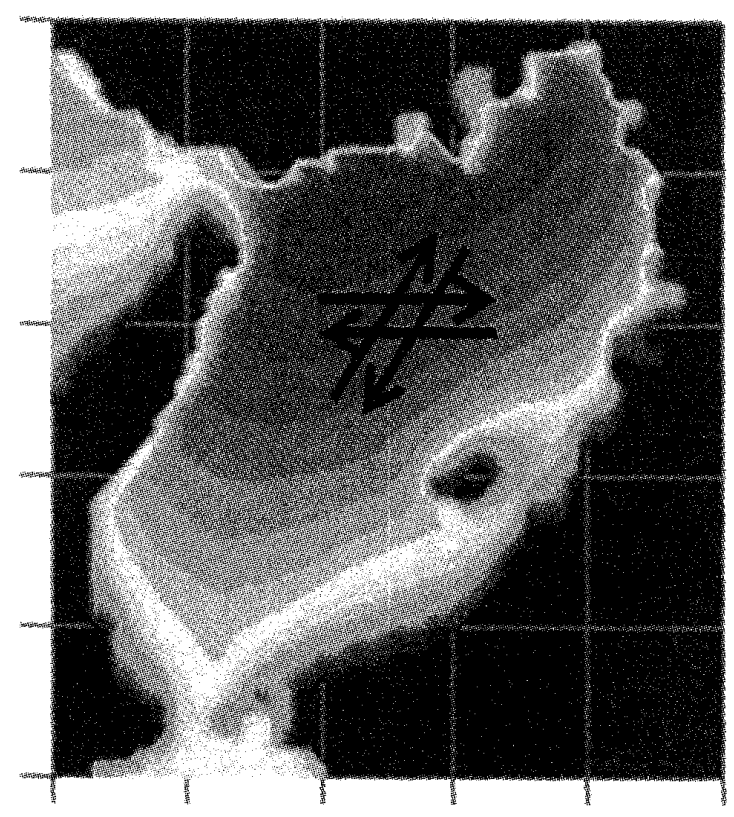

Fig.6 Virtual rout in numerical navigation 


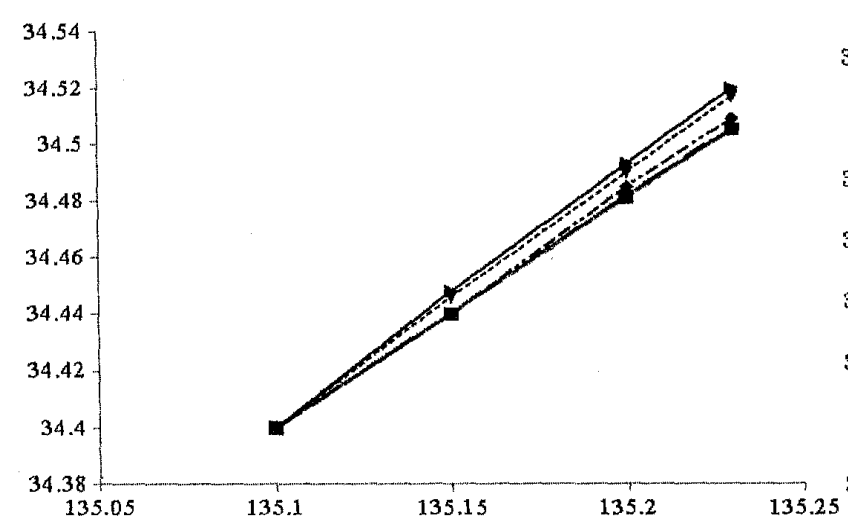

(a) Course $45^{\circ}$

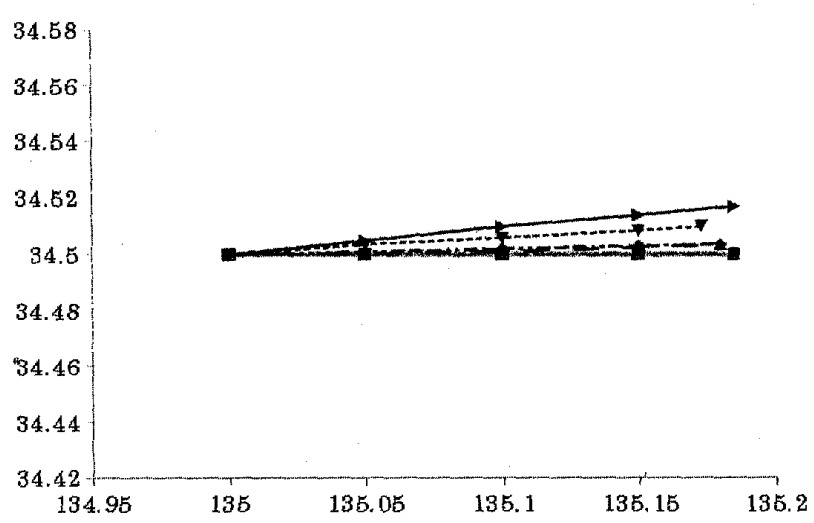

(c) Course $90^{\circ}$

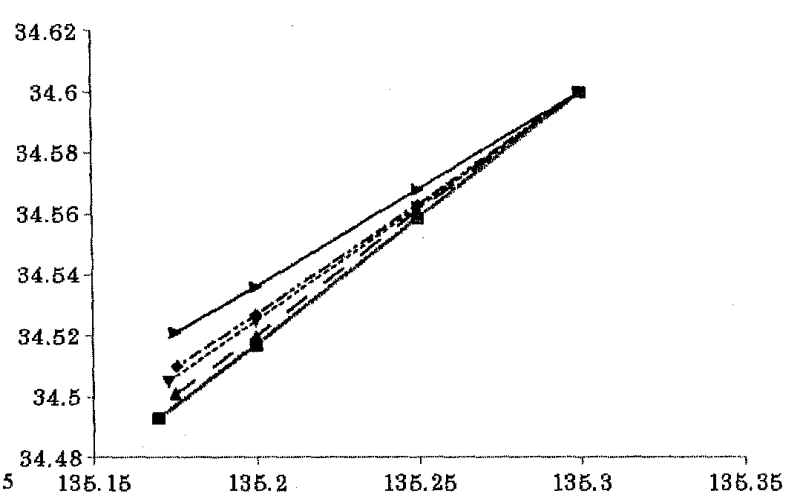

(b) Course $225^{\circ}$

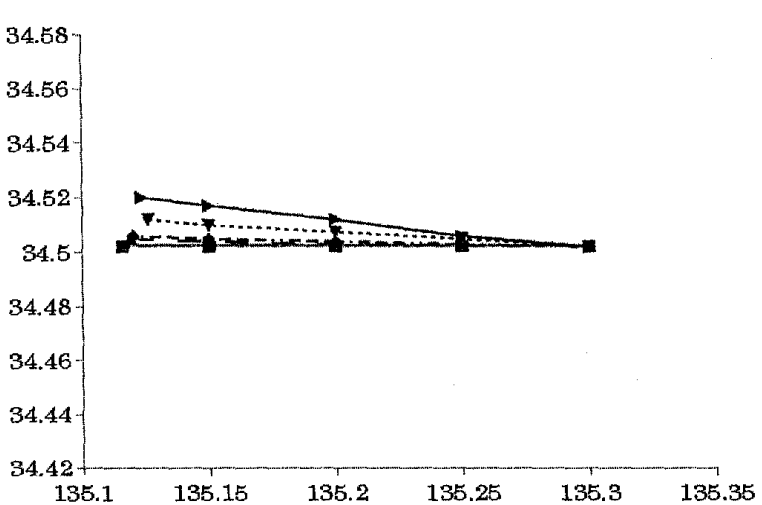

(d) Course $270^{\circ}$

$\rightarrow$ Setting rout - - - Wave -.- Tidal current $\longrightarrow$ Wind $\longrightarrow$ Wave, Tidal current, wind

Fig. 7 Numerical simulation of navigation by Fukaemaru in Osaka Bay

を用いた深江丸の航海シミュレーションを行った結 果を示す。縦軸及び横軸はそれぞれ緯度、経度であ る。実船は設定航路、点線は波浪のみの影響による 航跡、破線は潮流のみの影響による航跡、2 点鎖線 は風のみの影響による航跡、1 点鎖線は潮流、風及 び波浪全ての影響を考慮した航跡を示す。(a)図は追 い波、(b)図は向加波中の航行であり、後者の方が 速力低下及び船位の横流れ量が顕著に表れている。 (c)及び(d)図ではいずれも針路に対し横波を受ける ため、波浪の影響は小さい。潮流の強さ、流向によ りシミュレーション結果は当然異なるが、この計算 条件では潮流の影響が速力の増減、横流れ量に最も 影響するものと考えられる。波浪、風及び潮流の全 て考慮した航海への影響は、実船実験の検証が今 後の課題であるが、本研究で構築の航海シミュレー
ションにより、概ね再現可能であると考えられる。

\section{5. 結論}

本研究の目的は、波浪中の航行船舶に影響を与え る波浪の数值予測と波浪による船位の偏位量及び航 程の変化の予測を行うシステムの構築である。波浪 の数值シミュレーションを行い、その予測された波 浪場を模擬船舶が航海する航海シミュレーションを 行い、正確な船位予測が可能な手法の開発を行った。 その結果、本研究で得られた主要な結論は以下の通 りである。

（1）湾内などの沿岸域が航行海域である小型船舶 に対し、海域内の波浪の数值予報が SWAN モデルを 用いて可能となった。

（2）波浪中の船舶において、RIOS を用いた波浪 
定常外力の予測が可能となった。

（3） MMG モデルにより波浪、潮流及び風の影響 による航行船舶の横流れ量及び船速変化の予測が可 能となった。

（4）航行海域内の数值波浪シミュレーションに基 づいた、船位の予測が可能である航海シミュレーシ ヨンの確立が可能となつた。

本研究では、潮流、風及び波浪の影響を考慮した 航行船舶の正確な船位予報が航海シミュレーション においては可能となったが、今後実海域における実 船舶による検証を行う予定である。さらに、潮流、 風及び波浪の数值予測をそれぞれ個別に実施したが、 それぞれ互いに相互作用するので、これらの結合モ デルの構築を行う所存である。

本研究は、平成 20 年度に文部科学省から採択され た特別教育研究推進(研究推進)「輸送の三原則を統 合した国際海上輸送システム創出の研究」の一貫と して実施した。

\section{参考文献}

(1) 塩谷茂明: 小型船の航海のための潮流シミュレ ーション，日本航海学会論文集，第 98 号, pp.127-140, 1998

（2）塩谷茂明：潮流を利用した小型船の最短時間航 法の研究, 西部造船会会報, 第 100 号,pp.73-81, 2000

(3) Shigeaki SHIOTANI: Experimental Verification of Simulation for Navigation Utilizing Current Sailing, 関西造船協会論文集，第 238 号，pp.205-214， 2002

（4）夏海波、塩谷茂明、小林英一、若林伸和：リア ルタイム気象海象データを考慮した沿岸海域 航行船舶のウエザー・ルーチングに関する研究、 一船舶操縦性能を考慮した船位決定の基礎的 シミュレーションと実船実験一，関西造船協会 論文集、第 243 号、pp.159-166、2005

(5) 夏海波、塩谷茂明、小林英一、若林伸和：実小 型船舶を用いた風压による横流れの計測実験 とシミュレーションについて、日本航海学会論 文集、第 113 号、pp.171-177、2005

(6) Haibo XIA, Shigeaki SHIOTANI, Eiichi KOBAYASHI, Nobukazu WAKABAYASHI : Estimation of Ship's Course for Sailing on Route by Navigation Simulation in Coastal Water, The Journal of Japan Institute of Navigation, No.115, pp.51-57, 2006

（7）夏海波，塩谷茂明，万田敦昌，小林英一，若林
伸和：潮流シミュレーションを用いた航海への 潮流の影響の調査について，日本航海学会論文 集，第 116 号，pp.61-67，2007

（8）夏海波，塩谷茂明，大澤輝夫，小林英一：海上 風の数值予測と風圧影響下の航海シミュレー ション, 日本航海学会論文集, 第 117 号, pp.151-158，2007

（9）小林智尚，波浪推算システムとその応用，2002 年度(第 38 回)水工学に関する夏期研修講義集, 土木学会 海岸工学委員会・水理委員会, B-7-1 B-7-20, 2002

(10) 小林智尚，座波慎一郎，安田孝志，波浪推算モ デルSWANによる伊勢湾台風時波浪の再現，海 岸工学論文集, 第 50 巻,pp.181-185,2003

(11) 小川陽弘 : 操縦運動の数学的モデルの基礎，第 3 回操縦性シンポジウム, pp.9-26, 1981

(12) 小瀬邦治, 湯室彰擬規, 吉村康男: 操稀運動の 数学モデルの具体化, 第 3 回操縦性シンポジウ ム, pp.28-81, 1981

(13）実海域船舶性能研究イニシアティブ RIOS ホー ムページ、http://133.1.7.5/

\section{質疑応答}

林美鶴（神戸大学）：

（1）ご講演のシステムはナビゲーション計算に気 象・海象データのシミュレーションを含んでいる点 で特徴があるのだと理解しています。であれば、気 象・海象シミュレーション結果の精度が問題となり ます。実海域においては、潮流だけ、風圧流だけ、 吹走流だけを取り出して計算結果と比較することは 難しいと思います。シミュレーション結果が持つ誤 差要因をどのように評価されるのでしようか。

（2）大阪湾では、沖の瀬環流に代表されるような 潮汐残差流が卓越することが知られていますが、こ れは考慮されていますか。

\section{塩谷茂明：}

ご討論ありがとうございます。

（1）これまでの研究では、実船実験を行った結果 を公表しています。潮流に関しては、潮流の影響が 強い海域で風が弱い時間帯において、航跡を調査し ました。また、風に関しては、台風通過後の比較的 風が強く、潮流が弱い海域において調査しました。 これらの実船実験と潮流及び風の数值シミュレーシ ヨンを考慮した航海シミュレーションを比較検討し た結果、航海シミュレーションによる船位の予測が 概ね良好であることを確認しています。

波浪に関しては今後の研究として、潮流と風が弱 
く、比較的波浪が顕著な海域と時閒带を選んで実船 実験を行い、航海シミュレーションとの比較による 検証を行う予定です。

（2）現在、潮流の数值シミュレーションでは $\mathrm{M}_{2}$ 潮を境界条件とした計算しか行っていません。現在、 現実的な潮流計算を実施していますので、その結果 数值計算によりご指摘の残差流が再現できるから゙う か検討は可能です。航海シミュレーションに関して は、船舶が 2, 3 時間程度航行するのみであり、残差 流の影響はほとんどないのではと考えています。 河合雅司（富山高等專門学校）:

風、潮流、波浪について数値計算モデルにより推 定し、それらが船体運動に与える影響について紹介 されましたが、ここでの潮流は潮汐による海水の流 れであり、風が吹くことにより生じる海水の流れに ついてはどのように考慮されるお考えでしょうか。

\section{塩谷茂明 :}

ご討論ありがとうございます。ご指摘のとおり、 風が吹くことにより、潮流に風の影響の考慮が必要 です。これに関しては現在、風を考慮した潮流の数 值シミュレーションを計算中ですので、良い結果が 出ますと、今後公表したいと考えています。具体的 には、潮流のシミュレーションは POM を使用して いますが、このモデルには風の影響を取り込むこと が可能となっています。 